\section{Controlling Powdery Mildew in Euonymus with Polymer Coatings and Bicarbonate Solutions}

\author{
O. Ziv'and A. Hagiladi ${ }^{2}$ \\ Field Crop Institute, AgriculturalResearch Organization, The Volcani Center, \\ P.O. Box 6, Bet Dugan 50-250, Israel
}

Additional index words. Euonymus japonica, Oidium euonymi-japonica, disease control

Abstract. Powdery mildew in euonymus (Euonymus japonica Thunh.) plants, caused by Oidium euonymi-japonica (Arcang.) Sacc., was controlled by applying various polymer coatings or an aqueous solution of sodium or potassium bicarbonate plus horticultural Sun Spray (SS) Ultra Fine Oil 1\% (v/v) to plant foliage. The combined treatment (bicarbonate + oil) was more effective than either of the two materials alone. The results indicate that sodium or potassium (but not ammonium) bicarbonate solutions mixed with SS seems to be a useful biocompatible fungicide for controlling powdery mildew in euonymus plants. Some of the polymer coatings effectively reduced disease levels when applied immediately after the symptoms first appeared.

Powdery mildew disease caused by Oidium euonymi-japonica is severely destructive to euonymus plants from early spring until early autumn (Koul, 1980; Tokushige, 1953). Nademejad ( 1966) reported serious damage to E. japonica plants caused by the pathogen and stressed the need for chemical treatment to control powdery mildew. Chemical fungicides often fail to control foliar diseases, mainly because the pathogen develops resistance (Dekker, 1976). Various epidermal polymer coatings were effective in controlling powdery mildew on some other crops (Elad et al., 1990; Hagiladi and Ziv, 1986; Kamp, 1985; Ziv and Hagiladi, 1984). In China, the antitranspirant Masbrene (dodecyl alcohol; Aefachemi, Sheng Wan, Hong Kong) effectively controlled 12 foliar diseases on nine diverse hosts (Han Jing-Sheng, 1990).

When applied to leaves as a pre-inoculation treatment to prevent a pathogen from becoming established in plant tissue, protective coatings such as antitranspirants, oils, waxes, silicones, and various surfactant adhesives seem to be promising alternatives to chemical fungicides. In addition, these coatings do not pollute the environment as do chemical fungicides.

Powdery mildew on cucumber (Cucumis sativus L.) and roses (Rosa spp.) was controlled effectively by sodium and potassium bicarbonate solutions when mixed with surfactants (Homma et al., 1981) or horticultural oil (Horst et al., 1992) and applied to the leaves. The inhibitory effects of applying sodium or potassium bicarbonate solutions, alone or combined with Sun Spray (SS) Ultra-Fine Spray Oil (are fined petroleum distillate; Safer,

Received for publication 18 June 1992. Accepted for publication 23 Oct. 1992. The cost of publishing this paper was defrayed in part by the payment of page charges. Under postal regulations, this paper therefore must be hereby marked advertisement solely to indicate this fact.

'Dept. of Field Crops.

${ }^{2}$ Dept. of Floriculture and Ornamental Horticulture.
Newton, Mass.), to powdery mildew (Sphaerotheca fuliginea Schlechtend; Fr. Pollacci) on cucurbit foliage were demonstrated in greenhouse and field trials (Ziv and Zitter, 1992).

The purpose of this work was to evaluate the use of various coatings and bicarbonate solutions in controlling powdery mildews in E. japonica.

Table 1. Effect of polymer coatings on powdery mildew severity in Euonymus japonica (1990 trial).

\begin{tabular}{lcccr}
\hline \hline & \multicolumn{4}{c}{ Leaf area covered by pathogen (\%) } \\
\cline { 2 - 5 } Treatment & \multicolumn{4}{c}{ No. days after first treatment ${ }^{z}$} \\
\cline { 2 - 5 } & 14 & 26 & 40 & 55 \\
\hline Water (control) & $8.3^{\mathrm{y}} \mathrm{a}^{\mathrm{x}}$ & $19.3 \mathrm{a}$ & $28.6 \mathrm{a}$ & $41.2 \mathrm{c}$ \\
Spray \& Grow & $5.4 \mathrm{a}$ & $7.1 \mathrm{~b}$ & $11.9 \mathrm{~b}$ & $19.8 \mathrm{t}$ \\
Nu Film 17 & $5.7 \mathrm{a}$ & $6.0 \mathrm{~b}$ & $9.4 \mathrm{~b}$ & $13.1 \mathrm{t}$ \\
Bio-Film & $3.9 \mathrm{a}$ & $4.4 \mathrm{~b}$ & $4.8 \mathrm{c}$ & $5.9 \mathrm{c}$
\end{tabular}

"First treatment on 16 Mar. 1990 (1 day after symptoms appeared)

${ }^{\mathrm{r}}$ Mean of five branches $\times$ four plants (replications).

"Mean separation in columns by Duncan's multiple range test, $P=0.05$.

Table 2. Effect of bicarbonate solutions [with or without Sun Spray (SS) oil] and polymer coatings on powdery mildew severity in Euonymus japonica (1992 trial).

\begin{tabular}{lcccc}
\hline & \multicolumn{4}{c}{ Leaf area covered by pathogen (\%) } \\
\cline { 2 - 5 } Compound & \multicolumn{4}{c}{ No. days after first treatment } \\
\cline { 2 - 5 } and concn & $93.4^{2} \mathrm{a}^{\mathrm{x}}$ & 25 & 32 & 40 \\
\hline Water (control) & $21.8 \mathrm{de}$ & $25.1 \mathrm{a}$ & $98.2 \mathrm{a}$ & $100.0 \mathrm{a}$ \\
$\mathrm{KHCO}_{3}, 1 \%$ & $11.8 \mathrm{e}$ & $12.9 \mathrm{de}$ & $26.0 \mathrm{~cd}$ & $28.3 \mathrm{~cd}$ \\
$+\mathrm{SS}$, both $1 \%$ & $8.9 \mathrm{e}$ & $11.2 \mathrm{e}$ & $18.1 \mathrm{de}$ & $20.0 \mathrm{~d}$ \\
$2 \%+\mathrm{SS}, 1 \%$ & $15.2 \mathrm{e}$ & $18.6 \mathrm{~d}$ & $22.1 \mathrm{e}$ & $15.6 \mathrm{de}$ \\
NaHCO, $1 \%$ & $21.8 \mathrm{de}$ & $20.9 \mathrm{~d}$ & $23.2 \mathrm{~d}$ & $26.9 \mathrm{~d}$ \\
$+\mathrm{SS}$, both $1 \%$ & $9.1 \mathrm{e}$ & $10.5 \mathrm{e}$ & $12.9 \mathrm{e}$ & $14.1 \mathrm{de}$ \\
$2 \%+\mathrm{SS}, 1 \%$ & $58.2 \mathrm{~b}$ & $66.8 \mathrm{~b}$ & $72.0 \mathrm{ab}$ & $81.1 \mathrm{ab}$ \\
$\mathrm{NH}_{4} \mathrm{HCO}, 1 \%$ & $34.6 \mathrm{c}$ & $39.5 \mathrm{bc}$ & $40.1 \mathrm{~b}$ & $41.2 \mathrm{bc}$ \\
$+\mathrm{SS}$, both $1 \%$ & $25.7 \mathrm{~d}$ & $22.9 \mathrm{~d}$ & $29.1 \mathrm{~d}$ & $31.0 \mathrm{~d}$ \\
Bio-Film, $1 \%$ & $28.1 \mathrm{~d}$ & $22.9 \mathrm{~d}$ & $32.4 \mathrm{~cd}$ & $36.1 \mathrm{~cd}$ \\
NuFilm $17,1 \%$ & $42.2 \mathrm{bc}$ & $49.8 \mathrm{~b}$ & $39.8 \mathrm{bc}$ & $45.8 \mathrm{bc}$ \\
Anti-Stress, $1 \%$ & $19.8 \mathrm{~d}$ & $25.7 \mathrm{~cd}$ & $26.1 \mathrm{de}$ & $28.0 \mathrm{~d}$ \\
Masbrane, $1 \%$ & $64.2 \mathrm{~b}$ & $59.4 \mathrm{~b}$ & $67.0 \mathrm{~b}$ & $68.6 \mathrm{~b}$ \\
Bayleton & $31.8 \mathrm{~cd}$ & $33.5 \mathrm{~cd}$ & $36.0 \mathrm{~cd}$ & $39.1 \mathrm{c}$ \\
SS, $1 \%$ & & & & \\
\hline
\end{tabular}

${ }^{2}$ First treatment on 27 Mar. 1992.

${ }^{y}$ Five branches $x$ four plants served as replications for each treatment. Disease level is the percent leaf area (mean of 20 leaves for each treatment) covered by the pathogen out of total leaf area.

'Numbers followed by the same letter do not differ significantly in the column according to Duncan's multiple range test, $P=0.05$. 
treatment (total of 20 branches per treatment). Plastic sleeves $(20 \mathrm{~cm}$ in diameter and $60 \mathrm{~cm}$ long) were used during spraying to prevent contamination due to wind drift. Nontreated control branches were sprayed with water alone. In the second trial, four control plants were sprayed with the fungicide Bayleton (triadimefon) at $1 \mathrm{~g}$ a.i./liter.

Disease severity was evaluated weekly by visually estimating the percentage of leaf area covered by powdery mildew.

In the 1990 experiment, the three polymer coatings effectively prevented powdery mildew on $\boldsymbol{E}$. juponicu compared with control branches (Table 1). After 55 days, Bio-Film was superior to the other products examined. In the second experiment, only the two most effective polymer coatings were examinedBio-Film and Nu Film 17. The concentration of these two polymer coatings was $1 \%$ to learn the effect on powdery mildew at a reduced dose. During the growing season, young leaves were more vulnerable than older ones to pathogen attack and needed renewed protection every 10 days. A similarphenomenon was observed in roses (Hagiladi and Ziv, 1986).

In 1992, the most effective products in controlling powdery mildew in euonymus plants were $\mathrm{Na}$ and $\mathrm{K}$ bicarbonate $\left(\mathrm{HCO}_{3}^{-}\right)$ solutions (Table 2). The $\mathrm{NH}_{4}$ might be toxic in the concentration applied to the euonymus plants. This toxicity could enable powdery mildew to develop. Potassium and sodium bicarbonate solutions, in the presence of SS, and sodium bicarbonate alone, were significantly more effective than any of the polymer coatings.

Bio-Film, Nu Film 17, and Masbrane did not significantly differ in their ability to protect euonymus plants from powdery mildew. Anti-Stress was the least effective. The protection pattern obtained by the products examined was maintained over time (Table 2).

In cucurbits, using bicarbonate solutions combined with SS effectively controls powdery mildew (Ziv and Zitter, 1992). Sodium and potassium bicarbonate solutions at $1 \%$ or $2 \%$, when mixed with SS, reduced disease severity on euonymus plants to $12 \%$ to $21 \%$ of that on nontreated control plants (Table 2, Fig. 1). Ammonium bicarbonate had no such effect. The inhibitory effect of bicarbonate solutions mixed with oil lasted 10 to 14 days after treatment. Bayleton (Table 2) was ineffective in controlling powdery mildew on euonymus plants. The fungicides 1-[2-(2,4-dichlorophenyl)-4 propyl- 1,3 dioxolan-2-yhnethyl] $1 \boldsymbol{H}$ 1,2,4 triazol) [Tilt (propiconazole)] and methyl 1-(butylcarbamoyl)benzimidazol-2ylcarbamate [Banlate (triamefon)] also were ineffective in controlling powdery mildew on euonymus plants (unpublished data).

The results of this preliminary study indicate that it may be possible to replace conventional chemical fungicides with polymer coatings or bicarbonate salts, alone or in combination, as part of the integrated pest management strategy for controlling powdery mildew on euonymus plants.

A limitation encountered with these treatments was their failure to control powdery

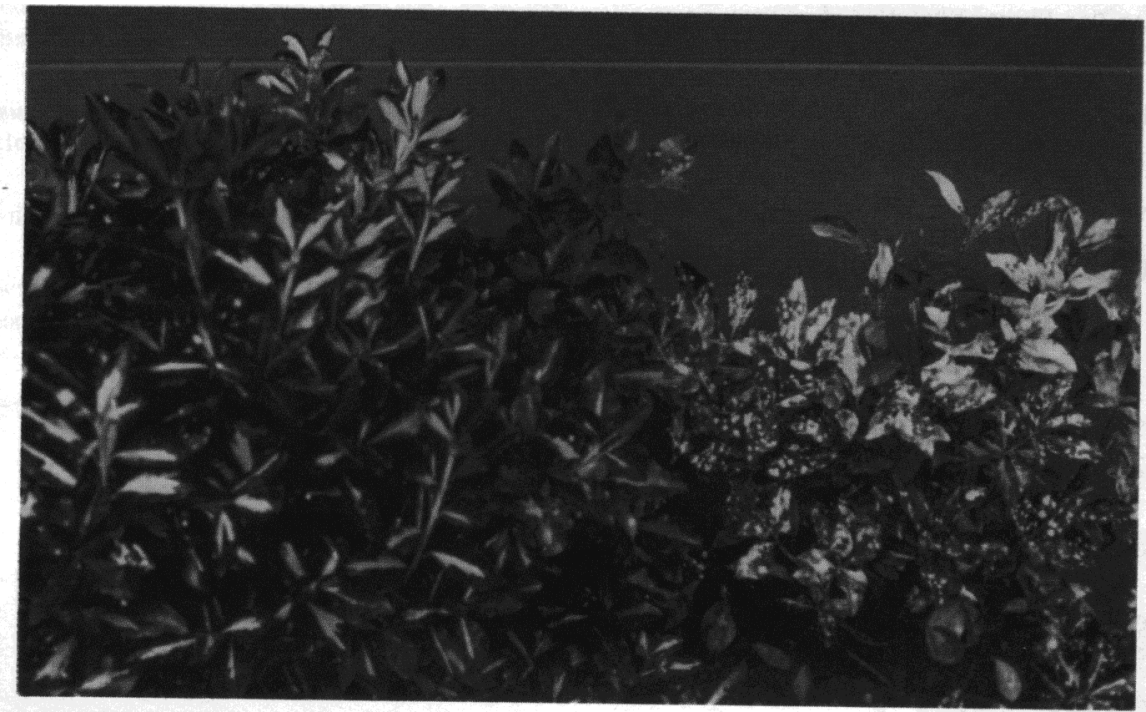

Fig. 1. Effect of $\mathrm{KHCO}_{3}+1 \%$ (v/v) Sun Spray oil on powdery mildew of Euonymus japonica plant (left) compared with nontreated control plant (right).

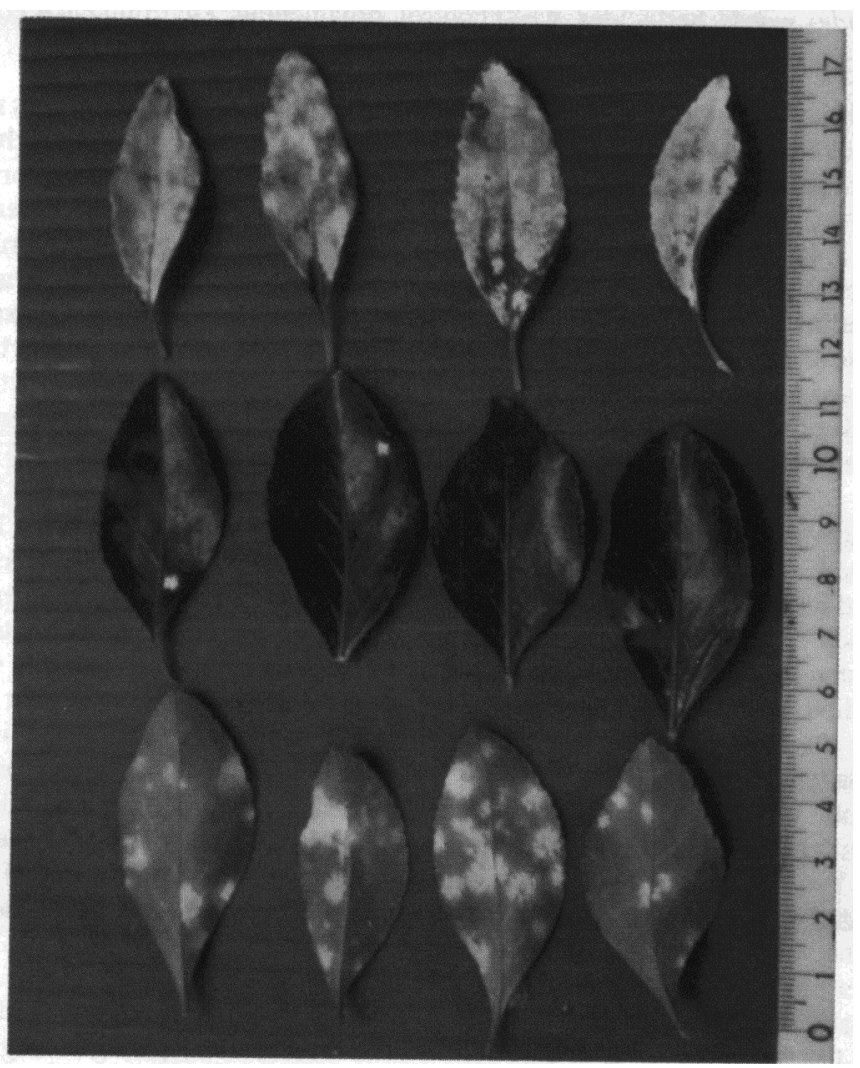

Fig. 2. Adaxial surface of nontreated leaves of euonymus plants (top), and of leaves treated with $\mathrm{KHCO}_{3}$ at $1 \%$ (center), and the abaxial side of leaves treated with $\mathrm{KHCO}_{3}$ (bottom).

mildew on the abaxial surface of the leaf, presumably because the coatings inadequately covered that surface (Fig. 2). Application technology improvements will maximize the amount of coating deposited on both leaf surfaces. Also, since control by these materials is protective in nature (Ziv and Zitter, 1992), they must be applied soon after the disease appears to be effective.

\section{Literature Cited}

Dekker, J. 1976. Acquired resistance to fungicides. Annu. Rev. Phytopathol. 14:405-428.

Elad, Y., O. Ziv, N. Ayish, and J. Katan. 1990. The effect of film-forming polymers on powdery mildew of cucumber. Phytoparasitica 17:279288.

Hagiladi, A. and O. Ziv. 1986. The use of antitranspirants for the control of powdery mildew on roses in the field. J. Environ. Hort. 4:69-71. 
Han Jing-Sheng. 1990. Use of antitranspirant epidermal coatings for plant protection in China. Plant Dis. 74:263-266.

Homma, Y., Y. Arimoto, and T. Misato. 1981 Effect of sodium bicarbonate on each growth stage of cucumber powdery mildew fungus (Sphaerotheca fuliginea) in its life cycle. J. Pesticide Sci. 6:201-209.

Horst, R.K., S.O. Kawamoto, and L.L. Porter. 1992. Effect of sodium bicarbonate and oils on the control of powdery mildew and black spot of roses. Plant Dis. 76:247-251
Kamp, M. 1985. Control of Erysiphe cichoracearum on Zinnia elegans with a polymer-based antitranspirant. HortScience 20:879-881.

Koul, A.K. 1980. Powdery mildew on Euonymus japonica in Kashmir. Indian Phytopathol. 21:507-508.

Nademejad, N. 1966 Euonymus japonicus in gardening. Iran J. Plant Pathol. 3:21-24.

Tokushige, Y. 1953. The effect of powdery mildew on Euоnimus japonicus. Ann. Phytopathol. Soc. Jpn. 17:61-64.
Ziv, O. and R.A. Frederiksen. 1986 The effect of film-forming antitranspirants on leaf rust and powdery mildew incidence on wheat. Plant Pathol. 36:242-245.

Ziv, O. and A. Hagiladi. 1984. Control of powdery mildew on hydrangea and crape myrtle with autitrauspirants. HortScience 19:708-709.

Ziv, O. and T.A. Zitter. 1992. Effect of bicarbonates and film-forming polymers on cucurbit foliar diseases. Plant Dis. 76:513-517. 